\title{
EVALUATION OF THE HUMAN IMMUNODEFICIENCY VIRUS TYPE 1 AND 2 ANTIBODIES DETECTION IN DRIED WHOLE BLOOD SPOTS (DBS) SAMPLES
}

\author{
Andréa Cauduro de CASTRO(1,3), Luiz Gustavo dos Anjos BORGES(4), Ricardo da Silva de SOUZA(4), Melina GRUDZINSKI(5) \& Pedro Alves D'AZEVEDO(2)
}

\begin{abstract}
SUMMARY
Human Immunodeficiency Vírus Type 1 and 2 antibodies detection was performed in 457 dried whole blood spots samples (S\&S 903). Q-Preven HIV 1+2 was the screening test used. The results were compared with the gold standard serum tests by ELISA (Cobas Core e Axsym HIV1/2 gO) and imunofluorescence was the definitive confirmatory test.

The samples were obtained from the Hospital Nossa Senhora da Conceição in Porto Alegre, RS - Brazil, through whole blood transfer to filter paper card and sent to Caxias do Sul, RS - Brazil where the tests were performed.

The dried whole blood spot stability was evaluated with two different panels. The first one was composed of five negative and five positive samples stored at room temperature, $4{ }^{\circ} \mathrm{C},-20{ }^{\circ} \mathrm{C}$ and $-70{ }^{\circ} \mathrm{C}$, while the second was composed of two negative and three positive samples stored at $37{ }^{\circ} \mathrm{C}$ (humidity <50\%). Each sample was screened every week for six weeks. These measurement results didn't show variation during the study period.

The detected sensibility was $100 \%$, specificity was $99.6 \%$, the positive predictive value was $99.5 \%$ and negative predictive values were $100 \%$. The results demonstrated high performance characteristics, opening a new perspective of dried whole blood spot utilization in HIV screening diagnosis.
\end{abstract}

KEYWORDS: Filter paper; HIV diagnosis; DBS stability.

\section{INTRODUCTION}

The UNAIDS and WHO estimated that 39.5 million [34.1 million - 47.1 million] people worldwide were living with HIV in 2006. New infections counted 4.3 million [3.6 million - 6.6 million] cases and 2.9 million [2.5 million - 3.5 million] lost their lives to AIDS. Global estimatives indicates that the HIV incidence rate peaked in the late 1990s and stabilized subsequently, notwithstanding increasing in many countries $^{29}$.

The utility of dried blood spots (DBS) for infectious disease testing has been known for years ${ }^{18}$. The need for an expanded HIV diagnostic coverage in Brazil is a challenging issue, due to Brazilian territorial extension and expressive number of isolated populations. In this study we evaluated the performance of HIV DBS testing, aiming towards new alternatives to address this problem.

The ease of using dried blood samples led them to be collected and stored under minimal conditions worldwide and without the need for sophisticated equipment or training $3,18,6,20,15$.

Risks associated with shipping are minimized as DBS cannot leak or be broken in transit and there is no requirement for carriage on dry ice. Handling of potentially infected material is also reduced as the need to centrifuge and separate sera from blood clots is eliminated ${ }^{25}$.

Dried blood spot can be used as an easy and inexpensive means for the collection and storage of specimens under field conditions for the diagnosis of HIV infection ${ }^{6}$.

The use of only a minute amount of whole peripheral blood allows collection of blood by heel prick, requiring less skill and fewer supplies. Once dry, blood samples on filter paper are no longer infectious and, coupled with an absence of glass, reduce the risk to health care workers $^{5,19}$.

Standardized dried whole blood spot, as used in many other infectious conditions, can be valuable resources on referencing samples to technologically capable HIV diagnostic sites ${ }^{12}$. Initial doubts over the sensitivity and the specificity of DBS based compared with serological assays were dispelled by parallel testing of DBS and sera which showed 99-100\% concordance. Furthermore extensive studies proved that concerns about the presence of haem in the eluate and adverse storage, for example in tropical conditions, causing false reactions were unfounded $d^{3,17,25}$. DBS has been used in large scale HIV surveillance studies for over a decade $\mathrm{e}^{16,26}$. 


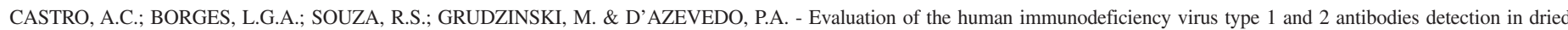
whole blood spots (DBS) samples. Rev. Inst. Med. trop. S. Paulo, 50(3): 151-156, 2008.

\section{OBJECTIVES}

The aim of this study was to evaluate the efficiency of the HIV antibodies detection in dried blood spot compared with the HIV antibodies detection in serum with the ELISA and confirmatory tests, according to Brazilian Ministry of Health algorithm (Portaria $\mathrm{n}^{\circ} 59$, $2003)^{8}$. Our specific objective was focused on HIV antibodies stability in DBS stored under multiple conditions of time and temperature. These results may contribute to the implement of HIV testing in remote areas and the coverage of HIV screening during pregnancy.

\section{MATERIALS AND METHODS}

Samples: Along 2005 to 2006, patients from the Grupo Hospitalar Conceição of Porto Alegre, RS, Brazil, tested for HIV were used. Patients ages varied between two months and 78 years. 457 samples were obtained. A dried whole blood spot panel was prepared by transferring $50 \mu \mathrm{L}$ of whole blood-EDTA specimens to collect card S\&S 903. Each collect card had five circles of about $13 \mathrm{~mm}$ of diameter. These samples were dried at room laboratory temperature for four hours prior to storage ${ }^{15,18,20}$.

The serum screening and confirmatory tests were performed in the Immunology Unit of Hospital Conceição Laboratory of Porto Alegre, as well as the whole blood samples transferred to the filter paper card. The Laboratory got the American College of Pathology certification to HIV diagnostic tests performed in this study.

The dried whole blood spot were sent, by mail, in zip lock plastic bags with desiccant silica, to HIV/AIDS Research Laboratory of the Caxias do Sul University and stored at room temperature, $4{ }^{\circ} \mathrm{C},-20{ }^{\circ} \mathrm{C}$ and $-70^{\circ} \mathrm{C}$. DBS were screened at weeks one and six for HIV antibodies by Q-Preven HIV 1+2. A sample group was stored at $37^{\circ} \mathrm{C}$ and screened at weeks one until five. All samples were sent without the knowledge of serological status. The whole laboratory procedures followed the Good Laboratory Practice and included all quality controls.

\section{Statistical calculations:}

Sensibility $=\frac{\text { true positive }}{\text { true positive }+ \text { false negative }} \times 100$

Specificity $=\frac{\text { true negative }}{\text { true negative }+ \text { false positive }} \times 100$

Positive predictive value $=\frac{\text { true positive }}{\text { true positive }+ \text { false positive }} \times 100$

Negative predictive value $=\frac{\text { true negative }}{\text { true negative }+ \text { false negative }} \times 100$

Filter paper (Schleicher\&Schuell, Keene, N.H.)

Filter paper grade 903 recommended by NCCLS (National
Committee on Clinical Laboratory Standards). Basis weight of $179 \mathrm{~g} /$ $\mathrm{m}^{2}$, thickness of $0.52 \mathrm{~mm}$, water absorbency of $4.44 \mathrm{~g} / 100 \mathrm{~cm}^{2}$ and wet strength of 3 psi.

\section{SCREENING TESTS}

\section{HIV combi EIA (COBAS CORE-Roche, Germany)}

This assay is a combination of a double antigen sandwich assay (antibody detection module) comprising antigens from the env region of HIV-1, HIV-2, HIV-1 Sub O and from the pol region of HIV-1 and a monoclonal antibody sandwich assay (antigen detection module) of four anti-p24 monoclonal antibodies. The anti-HIV/HIVAg combined assay was applied to the Roche COBAS CORE System by using recombinant antigens and anti-p24 monoclonal antibodies at the solid phase (beads), as well as Digoxigenin labeled anti-p24 monoclonal antibodies and peroxidase labeled antigens and anti-Digoxigenin. The bead is incubated with TMB substrate and the intensity of the resulting color is proportional to the amount of anti-HIV antibodies and HIV-1 p24 antigen detected in the specimen.

\section{HIV 1 /2 gO (AXSYM-Abbott Laboratories, USA)}

This test combines microparticle, fluorescent, and enzyme-linked immunoassay technologies into an automated, random-access system. Microparticles, the specimen dilution buffer, and the specimen are incubated together in the first step. Serum antibodies are captured via microparticle-bound recombinant proteins presenting key antigenic portions of the representative of HIV type 1 group $\mathrm{M}$, HIV-1 group O or HIV-2. After incubation, AXSYM transfers microparticles bearing immune complexes to a porous matrix and washes the matrix to remove all unbound components or materials.

In the second step, biotinylated probes (recombinant antigens and synthetic peptides) are added to microparticle-bound immune complexes. After an incubation period, AXSYM washes the matrix and removes unbound materials.

In the third step, biotinylated probes bound to the solid phase via sandwich formation reacted with an anti-biotin rabbit antibody complexed with alkaline phosphatase (conjugate). After another wash, AXSYM detects the formation of immune complexes by automated addition of 4-methylum-belliferyl phosphate, which is a fluorescent substrate for the alkaline phosphatase. The flourescent signal is detected and proportional to the amount of antibody contained in the serum sample.

CONFIRMATORY TEST: IFI HIV-1 (Bio-Manguinhos, Brazil)

This test is an indirect immunofluorescence to anti-HIV-1 antibodies detection. Serum antibodies react with K37-3 cells, infected by HIV-1, fixed on immunofluorescence microscope slides. Around $25-35 \%$ of cells own viral antigens suitable to be detected on the slide surface. The reaction between the slide antigen and the sample antibody is visualized after the fluorescein-isothiocyanate-conjugate human immunoglobulin addition in a special immunofluorescence microscope like brilliant stain cells.

FILTER PAPER TEST: Q-PREVEN HIV 1+2 - DBS (Brazil)

Enzyme immunoassay (EIA) Human Immunodeficiency Virus (HIV 1; HIV 2 and HIV 1 subtype O) antibodies detection in dried blood 
spot. A 4.7-mm punch from the DBS was eluted in $250 \mu \mathrm{L}$ of buffer. The eluate is dispensed in the appropriate well in the microplates with recombinant proteins (p24, gp41 of HIV-1 and gp35 of HIV-2) and HIV-1 subtype O synthetic peptide (gp41). In the first step, specific antibodies are captured by specific antigens in the microplate. In the second step, after aspiration and wash to remove all unbound materials, the immune complexes are detected by addition of recombinant proteins and synthetic peptides of HIV solution, conjugated with horseradish peroxidase (HRPO). After aspiration and wash, the solid phase is incubated with TMB substrate and the intensity of the resulting color is proportional to the amount of anti-HIV antibodies in the sample that can be read at $450 \mathrm{~nm}$.

The project was approved by the Ethics Committee of the Hospital Nossa Senhora da Conceição $n^{\circ}$ 042/05 and Ethics Committee of Fundação Faculdade Federal de Ciências Médicas de Porto Alegre $n^{\circ}$ 142/06.

\section{RESULTS}

From 457 samples, 268 were negative and 189 were positive on serologic tests. All 189 samples were also positive on DBS test. From the 268 negative samples on serologic tests, 267 were negatives on DBS test. The unmatched sample showed low optical density and triplet testing revealed a final negative result $(26 \mathrm{~N}$, Table 1$)$.

Table 1

Results from sample panel tested on Dried Blood Spot versus serum samples

\begin{tabular}{lccc}
\hline Samples & $\begin{array}{c}\text { Positives } \\
\text { on serum }\end{array}$ & $\begin{array}{c}\text { Negatives } \\
\text { on serum }\end{array}$ & Total \\
\hline Positives on DBS & 189 & 1 & 190 \\
Negatives on DBS & 0 & 267 & 267 \\
\hline Total & $\mathbf{1 8 9}$ & $\mathbf{2 6 8}$ & $\mathbf{4 5 7}$ \\
\hline
\end{tabular}

DBS dried blood spot

The sensibility, specificity, negative predictive value (NPV) and positivity predictive value (PPV) are present in Table 2.

Table 2

Diagnostic performance of Dried Blood Spot compared to standard diagnostic procedure

\begin{tabular}{lcccccc}
\hline & Positive & Negative & Sensibility & Specificity & PPV & NPV \\
\hline Serum & 189 & 268 & $100 \%$ & $100 \%$ & $100 \%$ & $100 \%$ \\
DBS & 190 & 267 & $100 \%$ & $99.6 \%$ & $99.5 \%$ & $100 \%$ \\
\hline
\end{tabular}

PPV - positive predictive value; NPV - negative predictive value; DBS dried blood spot.

The DBS stability on storage under temperature of $4{ }^{\circ} \mathrm{C},-20{ }^{\circ} \mathrm{C}$ and $-70{ }^{\circ} \mathrm{C}$ and humidity $<50 \%$ was $100 \%$, with optical density (OD) maintenance. Those stored under ambient temperature, mean $22.2{ }^{\circ} \mathrm{C}$ (range from 12.1 to 27.2 ) and humidity mean $59.5 \%$ (range from $72 \%$ to $45 \%$ ) maintained their optical densities on week one. On week six, one initially optical density low positive sample turned a negative result. On week one, an increase on optical density of one negative (204) sample was detected, but on week six, it became negative again, what suggests a contamination problem (Tables 3 and 4).

Table 3

Optical Density Ratio of the positive samples storaged in different temperature conditions

\begin{tabular}{lccc}
\hline Samples & Week 1 OD Ratio & Week 6 OD Ratio & Storage $\left({ }^{\circ} \mathrm{C}\right)$ \\
\hline $\mathbf{1 1 0}$ & 13.65 & 15.27 & -70 \\
$\mathbf{1 1 1}$ & 13.65 & 15.27 & -70 \\
$\mathbf{1 1 2}$ & 13.65 & 11.72 & -70 \\
$\mathbf{1 1 3}$ & 13.65 & 14.12 & -70 \\
$\mathbf{1 1 4}$ & 5.10 & 4.00 & -70 \\
$\mathbf{1 1 0}$ & 13.65 & 15.27 & 4 \\
$\mathbf{1 1 1}$ & 13.65 & 15.27 & 4 \\
$\mathbf{1 1 2}$ & 13.65 & 10.51 & 4 \\
$\mathbf{1 1 3}$ & 13.65 & 15.27 & 4 \\
$\mathbf{1 1 4}$ & 5.71 & 3.92 & 4 \\
$\mathbf{1 1 0}$ & 12.87 & 13.72 & -20 \\
$\mathbf{1 1 1}$ & 13.65 & 15.27 & -20 \\
$\mathbf{1 1 2}$ & 13.65 & 12.27 & -20 \\
$\mathbf{1 1 3}$ & 13.65 & 15.27 & -20 \\
$\mathbf{1 1 4}$ & 6.04 & 3.95 & -20 \\
$\mathbf{1 1 0}$ & 13.65 & 15.27 & Amb \\
$\mathbf{1 1 1}$ & 13.65 & 13.68 & Amb \\
$\mathbf{1 1 2}$ & 13.15 & 8.83 & Amb \\
$\mathbf{1 1 3}$ & 13.25 & 15.27 & Amb \\
$\mathbf{1 1 4}$ & 6.45 & 0.95 & Amb \\
\hline
\end{tabular}

$\overline{\mathrm{OD}}=$ Optical Density; OD ratio $=$ Sample Optical Density/cutoff; Cutoff = Negative Control +0.1800 .

Samples stored at $37{ }^{\circ} \mathrm{C}$ with air humidity maintained under $50 \%$ showed stable results pattern on the first three weeks of analysis. After the week four, the positive samples optical densities showed a decrease, most of them crossing the positivity threshold on week five. The negative samples did not show any variation (Table 5).

One positive sample with optical density (OD) 4.00 has been processed with 10 consecutive dilutions until 1:1024. The result curve is showed on Figure 1, the sample remaining positive until 1:256 dilution.

\section{DISCUSSION}

Our study showed adequate diagnostic performance of DBS testing when compared to standard diagnostic procedures. The detected sensibility was $100 \%$, specificity was $99.6 \%$, negative predictive value (NPV) was $100 \%$ and the positive predictive value (PPV) was $99.5 \%$ due to a false positive sample that failed to be confirmed on triplet testing. This particular case was considered a contamination problem of the initial testing. DBS stability was also accessed under various environmental and timing conditions. The samples stored under low temperatures $\left(4{ }^{\circ} \mathrm{C},-20{ }^{\circ} \mathrm{C}\right.$ and $\left.-70{ }^{\circ} \mathrm{C}\right)$ revealed an excellent stability until week six, maintaining the initial diagnostic result. One false positive result was detected among room temperature (range at $22.2^{\circ} \mathrm{C}$ ) 


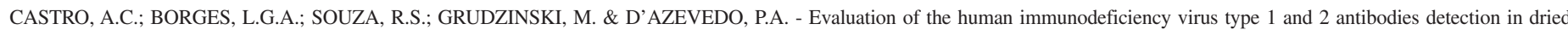
whole blood spots (DBS) samples. Rev. Inst. Med. trop. S. Paulo, 50(3): 151-156, 2008.

stored samples on week one. The same sample showed a negative result on week six.

Table 4

Optical Density Ratio of the negative samples storaged in different temperature conditions

\begin{tabular}{|c|c|c|c|}
\hline Samples & Week 1 OD Ratio & Week 6 OD Ratio & Storage $\left({ }^{\circ} \mathrm{C}\right)$ \\
\hline 204 & 0.47 & 0.42 & -70 \\
\hline 205 & 0.47 & 0.37 & -70 \\
\hline 206 & 0.73 & 0.35 & -70 \\
\hline 207 & 0.38 & 0.34 & -70 \\
\hline 208 & 0.43 & 0.47 & -70 \\
\hline 204 & 0.41 & 0.59 & 4 \\
\hline 205 & 0.41 & 0.39 & 4 \\
\hline 206 & 0.42 & 0.39 & 4 \\
\hline 207 & 0.23 & 0.40 & 4 \\
\hline 208 & 0.35 & 0.81 & 4 \\
\hline 204 & 0.53 & 0.45 & -20 \\
\hline 205 & 0.49 & 0.34 & -20 \\
\hline 206 & 0.33 & 0.43 & -20 \\
\hline 207 & 0.38 & 0.35 & -20 \\
\hline 208 & 0.29 & 0.29 & -20 \\
\hline 204 & 1.88 & 0.55 & $\mathrm{Amb}$ \\
\hline 205 & 0.48 & 0.48 & $\mathrm{Amb}$ \\
\hline 206 & 0.39 & 0.62 & $\mathrm{Amb}$ \\
\hline 207 & 0.41 & 0.71 & $\mathrm{Amb}$ \\
\hline 208 & 0.33 & 0.48 & $\mathrm{Amb}$ \\
\hline
\end{tabular}

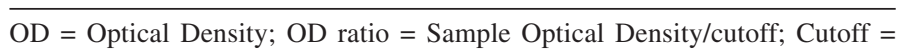
Negative Control +0.1800 .
Weekly analysis of samples stored under $37^{\circ} \mathrm{C}$ revealed reliable positive results until the third week. Optical density decrease was detected on the fourth and fifth weeks, however all samples had positive status maintained.

In spite of the absence of borderline optical density, the dilution sample performance proved good test sensibility.

Mother-to-child transmission (MTCT) is the dominant mode of acquisition of HIV-1 among young children worldwide, and most of them occur in late pregnancy, during labor or in the delivery. Postnatal transmission through breastfeeding is estimated to contribute with onethird to one-half of HIV-1 infections in children worldwide $^{2,9,11,13,14,21,22,23}$.

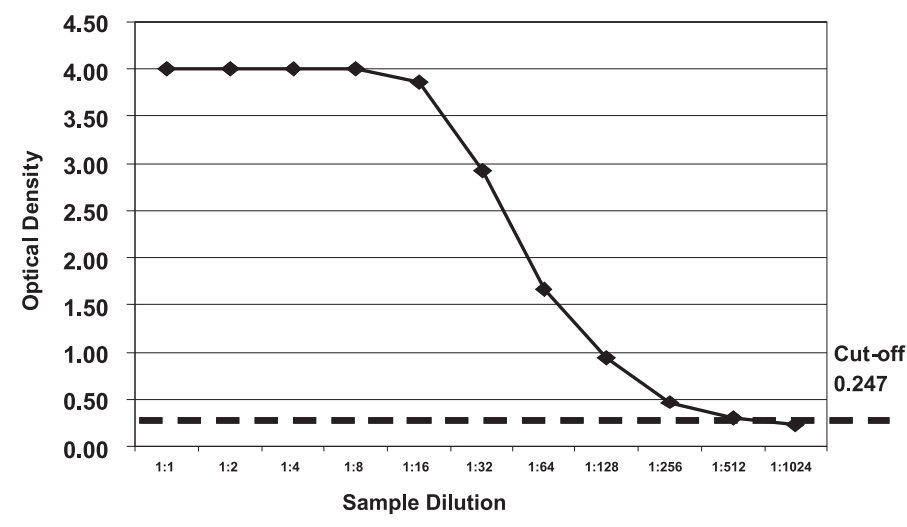

Cutoff $=$ Negative Control +0.1800 .

Fig. 1 - Positive sample with consecutive dilutions procedures.

Table 5

Dried Blood Spot Sample performance storaged at $37^{\circ} \mathrm{C}$ for five weeks

\begin{tabular}{|c|c|c|c|c|c|c|c|c|c|c|c|c|c|c|c|}
\hline $\begin{array}{l}\text { Time of } \\
\text { Storage at } \\
37{ }^{\circ} \mathrm{C}\end{array}$ & & Week & & & Weeks & & & Weeks & & & Weeks & & & Week & \\
\hline Samples & OD & $\begin{array}{c}\text { OD } \\
\text { ratio }\end{array}$ & Humidity & OD & $\begin{array}{c}\text { OD } \\
\text { ratio }\end{array}$ & Humidity & OD & $\begin{array}{c}\text { OD } \\
\text { ratio }\end{array}$ & Humidity & OD & $\begin{array}{c}\text { OD } \\
\text { ratio }\end{array}$ & Humidity & OD & $\begin{array}{c}\mathrm{OD} \\
\text { ratio }\end{array}$ & Humidity \\
\hline 58630 & 0.162 & 0.62 & $<50 \%$ & 0.083 & 0.33 & $<50 \%$ & 0.091 & 0.36 & $<50 \%$ & 0.057 & 0.24 & $<50 \%$ & 0.059 & 0.25 & $<50 \%$ \\
\hline 58579 & 0.082 & 0.31 & $<50 \%$ & 0.106 & 0.42 & $<50 \%$ & 0.08 & 0.31 & $<50 \%$ & 0.055 & 0.23 & $<50 \%$ & 0.057 & 0.24 & $<50 \%$ \\
\hline 58948 & 4 & 15.27 & $<50 \%$ & 3.569 & 14.00 & $<50 \%$ & 3.297 & 12.93 & $<50 \%$ & 2.853 & 12.14 & $<50 \%$ & 1.329 & 5.66 & $<50 \%$ \\
\hline 54138 & 2.304 & 8.79 & $<50 \%$ & 1.449 & 5.68 & $<50 \%$ & 1.555 & 6.10 & $<50 \%$ & 1.172 & 4.99 & $<50 \%$ & 0.941 & 4.00 & $<50 \%$ \\
\hline 58938 & 3.205 & 12.23 & $<50 \%$ & 2.195 & 8.61 & $<50 \%$ & 1.497 & 5.87 & $<50 \%$ & 0.933 & 3.97 & $<50 \%$ & 0.453 & 1.93 & $<50 \%$ \\
\hline White & 0.033 & 0.13 & & 0.04 & 0.16 & & 0.04 & 0.16 & & 0.047 & 0.20 & & 0.047 & 0.20 & \\
\hline $\begin{array}{l}\text { Positive } \\
\text { control }\end{array}$ & 3.673 & 14.02 & & 3.019 & 11.84 & & 3.019 & 11.84 & & 3.31 & 14.09 & & 3.31 & 14.09 & \\
\hline $\begin{array}{l}\text { Negative } \\
\text { control }\end{array}$ & 0.082 & 0.31 & & 0.075 & 0.29 & & 0.075 & 0.29 & & 0.055 & 0.23 & & 0.055 & 0.23 & \\
\hline Cut-off & 0.262 & & & 0.255 & & & 0.255 & & & 0.235 & & & 0.235 & & \\
\hline Test time & \multicolumn{3}{|c|}{$9 / 19 / 2006$} & \multicolumn{3}{|c|}{$10 / 2 / 2006$} & \multicolumn{3}{|c|}{$10 / 2 / 2006$} & \multicolumn{3}{|c|}{$10 / 13 / 2006$} & \multicolumn{3}{|c|}{$10 / 13 / 2006$} \\
\hline
\end{tabular}

OD = Optical Density; OD ratio = Sample Optical Density/cutoff; Cutoff = Negative Control +0.1800. 


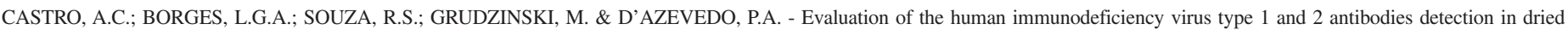
whole blood spots (DBS) samples. Rev. Inst. Med. trop. S. Paulo, 50(3): 151-156, 2008.

Marked changes have occurred in mother-to-child transmission of HIV in the United States and other developed countries since 1994, when the Pediatric AIDS Clinical Trials Group (PACTG) protocol 076 showed that the administration of zidovudine to HIV-infected woman during pregnancy and labor and to her newborn decreased the risk of perinatal HIV transmission ${ }^{6,7,8,10,12,13}$. Perinatal HIV infection has diminished to less than $2 \%$ after the implementation of recommendations for universal prenatal HIV counseling and testing, antiretroviral prophylaxis and elective cesarean delivery and avoidance of breastfeeding ${ }^{1,7,9,21}$.

Brazilian AIDS incidence showed expressive changes since the early $80 \mathrm{~s}^{28}$. The epidemiological pattern moved from a highly regional and minority-specific profile to a country-wide epidemic in the $90 \mathrm{~s}$. Regarding to HIV modes of transmission, heterosexual is the predominant. This resulted in a rapid increase in HIV infection among women, mostly of childbearing age. In parallel, there has been an increase in the number of perinatally infected children ${ }^{24,28}$. In June $2000,6,750$ cases of AIDS in Brazilian children were reported. In spite of the wide availability of specific antiretroviral therapy in Brazil, some regions remain with poor diagnostic conditions, specially related to pregnancy testing, screening strategies and confirmation procedures ${ }^{27}$.

These results may contribute with new strategies of HIV diagnostic routines and logistics in our country. The possibility of room temperature storage, mail shipping and laboratorial procedures concentrated in reference sites indicates that a broader diagnostic coverage may be offered maintaining the testing standard performances. The impact on the prevention of MTCT ought to be particularly beneficial as zidovudine is distributed by governmental health units, but diagnostic availability remain the main obstacle to lowering pediatric AIDS incidence.

\section{RESUMO}

\section{Pesquisa de anticorpos contra o vírus da imunodeficiência humana tipos 1 e 2 em amostras de sangue seco coletadas em papel filtro}

Foram realizados 457 testes para detectar anticorpos contra o Vírus da Imunodeficiência Humana tipos 1 e 2, em amostras de sangue total seco coletadas em papel filtro ( $\& \& S$ 903), com o teste de triagem QPreven HIV 1+2, comparando-se com os resultados dos testes de triagem no soro (Cobas Core e Axsym HIV1/2 gO), sendo a imunofluorescência indireta o teste confirmatório.

As amostras foram obtidas no Hospital Conceição em Porto Alegre, pela transferência de sangue total para cartão de papel filtro e encaminhadas para Caxias do Sul para a realização dos testes.

Foi analisada a estabilidade da amostra em papel filtro com a utilização de dois painéis: o primeiro com cinco amostras negativas e cinco positivas armazenadas por seis semanas à temperatura ambiente, $4{ }^{\circ} \mathrm{C},-20{ }^{\circ} \mathrm{C}$ e $-70{ }^{\circ} \mathrm{C}$; o segundo com duas negativas e três positivas armazenadas por seis semanas com avaliações semanais a $37{ }^{\circ} \mathrm{C}$ (umidade $<50 \%$ ). Os resultados de todas as amostras testadas foram mantidos.

A sensibilidade foi de $100 \%$, a especificidade de $99,6 \%$, o valor preditivo positivo de $99,5 \%$ e o valor preditivo negativo de $100 \%$. O excelente desempenho observado na análise da utilização de sangue seco em papel filtro, abre uma nova perspectiva no diagnóstico da infecção pelo HIV.

\section{REFERENCES}

1. ABRAMS, E.J. - Prevention of mother-to-child transmission of HIV-successes, controversies and critical questions. AIDS Rev., 6: 131-143, 2004.

2. AHMAD, N. - The vertical transmission of human immunodeficiency virus type 1 : molecular and biological properties of the virus. Crit. Rev. clin. Lab. Sci., 42: 1-34, 2005.

3. ARYA, S.C. - Stability of human immunodeficiency virus type 1 antibodies in whole blood impregnated filter papers under various tropical conditions. J. clin. Microbiol., 31: 765-766, 1993.

4. BARIN, F.; PLANTIER, J.C.; BRAND, D. et al. - - Human immunodeficiency virus serotyping on dried serum spots as a screening tool for the surveillance of the AIDS epidemic. J. med. Virol., 78: S13-S18, 2006.

5. BECK, I.A.; DRENNAN, K.D.; MELVIN, A.J. et al. - Simple, sensitive, and specific detection of human immunodeficiency virus type 1 subtype B DNA in dried blood samples for diagnosis in infants in the field. J. clin. Microbiol., 39: 29-33, 2001.

6. BRAMBILLA, D.; JENNINGS, C.; ALDROVANDI, G. et al. - Multicenter evaluation of use of dried blood and plasma spot specimens in quantitative assays for human immunodeficiency virus RNA: measurement, precision, and RNA stability. J. clin. Microbiol., 41: 1888-1893, 2003.

7. BRANSON, B.M.; HANDSFIELD, H.H.; LAMPE, M.A. et al. - Revised recommendations for HIV testing of adults, adolescents, and pregnant women in health-care settings. M.M.W.R., 55(RR-14): 1-17, 2006.

8. BRASIL. Ministério da Saúde - Novo algoritmo do diagnóstico sorológico da infecção pelo HIV e Programa de Controle da Qualidade Analítica do Diagnóstico Laboratorial da Infecção pelo HIV. Brasília, Portaria $\mathrm{N}^{\circ} 59$, de 28 de janeiro de 2003 do Programa Nacional de DST/AIDS, 2003.

9. BULTERYS, M. - Preventing vertical HIV transmission in the year 2000: progress and prospects. A review. Placenta, 22 (suppl. A): S5-S12, 2001.

10. CONNOR, E.M.; SPERLING, R.S.; GELBER, R. et al. - Reduction of maternal-infant transmission of human immunodeficiency virus type 1 with zidovudine treatment. Pediatric AIDS Clinical Trials Group Protocol 076 Study group. New Engl. J. Med., 331: 1173-1180, 1994.

11. COOVADIA, H.M. \& COUTSOUDIS, A. - HIV in pregnancy: strategies for management. Semin. Neonatol., 5: 181-188, 2000.

12. FRÓMETA-SUÁREZ, A.; MARRERO-GONZÁLEZ, N.; GONZÁLEZ-REYES, E. et al. - Estudio comparativo de los tres papeles de filtro en los ensayos UMELISA para el tamizaje neonatal de hipotiroidismo congénito y fenilcetonuria. Rev. Bioméd. (Méx.), 13: 241-247, 2002.

13. GIAQUINTO, C.; RUGA, E.; GIACOMET, V.; RAMPON, O. \& D'ELIA, R. - HIV: mother to child transmission, current knowledge and on-going studies. Int. J. Gynaec. Obstet., 63 (suppl. 1): S161-S165, 1998.

14. GILlET, J.Y.; BONGAIN, A.; MONPOUX, F. \& MARIANI, R. - La transmission maternofetale du HIV. Arch. Pediat., 2: 169-172, 1995.

15. GRANADE, T.C.; PAREKH, B.S.; TIH, M.P. et al. - Evaluation of rapid prenatal human immunodeficiency virus testing in rural Cameroon. Clin. diagn. Lab. Immunol., 12: $855-860,2005$.

16. GWINN, M.; PAPPAIOANOU, M.; GEORGE, J.R. et al. - Prevalence of HIV infection in childbearing women in the United States. Surveillance using newborn blood samples. J. Amer. med. Ass., 265: 1704-1708, 1991. 


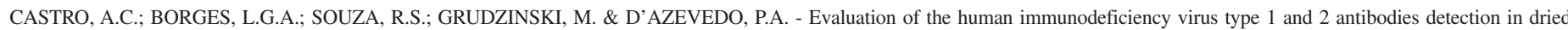
whole blood spots (DBS) samples. Rev. Inst. Med. trop. S. Paulo, 50(3): 151-156, 2008.

17. HANNON, W.H.; LEWIS, D.S.; JONES, W.K. \& POWELL, M.K. - A quality assurance program for human immunodeficiency virus seropositivity screening of dried-blood spot specimens. Infect. Control Hosp. Epidem., 10: 8-13, 1989.

18. HOGREFE, W.R.; ERNST, C. \& SU, X. - Efficiency of reconstitution of immunoglobin $\mathrm{G}$ from blood specimens dried on filter paper and utility in herpes simplex virus type-specific serology screening. Clin. diagn. Lab. Immunol., 9: 1338-1342, 2002.

19. KNUDSEN, R.C.; SLAZYK, W.E.; RICHMOND, J.Y. \& HANNON, W.H. - Guidelines for the shipment of dried blood spot specimens. Atlanta, Office of Health and Safety, Center for Disease Control and Prevention, 1993. (Document 101011).

20. MEI, J.V.; ALEXANDER, J.R.; ADAM, B.W. \& HANNON, W.H. - Use of filter paper for collection and analysis of human whole blood specimens. J. Nutr., 131: 1631S1636S, 2001.

21. MOFENSON, L.M. - Advances in the prevention of vertical transmission of human immunodeficiency virus. Semin. Pediat. infect. Dis., 14: 295-308, 2003.

22. NEWELL, M.L. - Antenatal and perinatal strategies to prevent mother-to-child transmission of HIV infection. Trans. roy. Soc. trop. Med. Hyg., 97: 22-24, 2003.

23. NEWELL, M.L. - Vertical transmission of HIV-1: risks and prevention. J. Hosp. Infect., 30: 191-196, 1995.
24. NOGUEIRA, S.A.; ABREU, T.; OLIVEIRA, R. et al. - Successful prevention of HIV transmission from mother to infant in Brazil using a multidisciplinary team approach. Braz. J. infect. Dis., 5: 78-86, 2001.

25. PARKER, S.P. \& CUBITT, W.D. - The use of the dried blood spot sample in epidemiological studies. J. clin. Path., 52: 633-639,1999.

26. ROLINS, N.C.; DEDICOAT, M.; DANAVIAH, S. et al. - Prevalence, incidence, and mother-to-child transmission of HIV-1 in rural South Africa. Lancet, 360(9330): $389,2002$.

27. SZWARCWALD, C.L.; BARBOSA JR., A. \& FONSECA, M.G.P. - Estimativa do número de crianças (0-14 anos) infectadas pelo HIV, Brasil, 2000. Bol. epidem. AIDS, 15(1): 49-54, 2001

28. SZWARCWALD, C.L.; BASTOS, F.I.; ESTEVES, M.A. \& ANDRADE, C.L. - A disseminação da epidemia da aids no Brasil, no período 1987-1996: uma análise espacial. Cadern. Saúde públ. (Rio de J.), 16 (suppl. 1): 7-19, 2000.

29. UNAIDS - 2006 AIDS epidemic update. Geneva, UNAIDS, 2006

Received: 28 December 2006

Accepted: 4 April 2008 